\title{
READING PSALM 78 MULTIDIMENSIONALLY: THE DIMENSION OF THE READER ${ }^{1}$
}

\author{
Yeol Kim, HF van Rooy \\ Potchefstroom Campus \\ North-West University
}

\begin{abstract}
This article is the third and final one in a series of articles on Psalm 78. The different articles are part of an experiment in a multidimensional reading and each of them deals independently with an aspect of the interpretation of Psalm 78. While the previous two articles deal with the textual and authorial dimensions of Psalm 78, this article will deal with the dimension of the reader and will make some final concluding remarks on the whole series. The diachronic aspect of the reader, on the one hand, can be described from the first (original) hearers/readers of the text up to modern readers because reception is an ongoing process which constitutes a continuation of the diachronic aspect. On the other hand, the synchronic aspect of the reader is constituted by the context in which and from which readers operate. As stated in the first article of this series accepting the principle of a pluralism of exegetical methodologies is a methodological presupposition for this study. Based on this presupposition various exegetical methods that elucidate the meaning of the psalm have been employed in this study. As basis for this plurality of exegetical methodologies, the communication model has been adapted as hermeneutical framework. As a result, the three basic elements of the communication process (the sender, the medium, and the receiver) constitute the model of this multidimensional reading of Psalm 78. Based on the mutual relationship between diachronic and synchronic aspects, the investigation of the heading, of the tradition history, of the dating and the historical setting (with Sitz im Leben), and the study of the canonical shape of Psalm 78 have all contributed to yield some new and fresh insight for understanding the psalm's own genesis.
\end{abstract}

Key Concepts: Psalm 78, reader, multidimensional interpretation, rhetorical critisism

\section{Introduction}

This article is the third and final one in a series of articles on Psalm 78. The different articles are part of an experiment in a multidimensional reading and each of them deals independently with an aspect of the interpretation of Psalm 78. While the previous two articles (see Kim and Van Rooy, 2000 and 2002) deal with the textual and authorial dimensions of Psalm 78, this article will deal with the dimension of the reader and will make some final concluding remarks on the whole series.

This article is partly based on Y Kim's ThM-dissertation: Reading Psalm 78 multidimensionally. Cf. Kim (1999). 


\section{An Introduction to the Dimension of the Reader in the Reading Process}

According to Jonker (1996:404-405), the diachronic aspect of the reader, on the one hand, can be described from the first (original) hearers/readers of the text up to modern readers because reception is an ongoing process which constitutes a continuation of the diachronic aspect. On the other hand, the synchronic aspect of the reader is constituted by the context in which and from which readers operate. The interaction between text and reader is also analogous to the interaction between author and text. Whereas the synchronic aspect of the author provides the basis for the interaction between author and text, the synchronic aspect of the reader now provides the basis for the interaction between text and reader (cf. Conradie et al, 1998:144-145).

The multidimensional aspects of the reader can be investigated by means of rhetorical analysis since rhetorical analysis focuses on the effect that is attained when the text is read by readers in a specific context (Conradie et al, 1998:145). Rhetorical analysis, therefore, seeks effective communication in the mutual relationship of the author, the text, and the hearers/readers by employing a specific literary method that will enable the critic to study the discourse strategy and techniques of effective communication systematically (see Gitay, 1993:135-136). The study of rhetorical analysis is a classical discipline that goes back to Aristotle. Rhetoric, according to Aristotle's classical definition, is "the faculty of discerning the possible means of persuasion in each particular case" (Aristotle, 1926:xxxii). Rhetorical analysis is a pragmatic method of analysis that integrates the three dimensions of a literary work: the author, the text itself, and the audience/readers. The author/speaker establishes his or her thematic goal through the transmission of his or her thought into a text (speech). The hearers'/readers' situation, ways of perception, and set of mind are also taken into consideration by the author/speaker (Gitay, 1993:136).

As a contemporary methodology for the study of the Bible rhetorical analysis is relatively recent, having first been introduced by James Muilenburg, in a seminal article entitled "Form Criticism and Beyond" (Muilenburg, 1969:1-18). Muilenburg's approach, however, is an expression of a stylistic-formalist awareness rather than a systematic study of early Hebrew rhetoric, since Muilenburg's "rhetorical criticism" focuses on stylistic phenomena such as figurative language and relationships of sounds as ends in themselves (Gitay, 1993:136). Reduced to concerns of style, with the artistry of textual disposition and textual structure, "rhetorical criticism" has become indistinguishable from literary criticism (Wuellner, 1987:451-452). Consequently, rhetorical critics have, in recent years, recognized the significance of the reader's response to the text (see Watson and Hauser, 1994:13). For that reason, the recent discussions in rhetorical analysis call for a change to expand the scope of the method beyond a descriptive study of stylistics in order to probe the persuasive power of texts to influence action or practice. In this regard, rhetorical analysis asks historical questions, when texts are studied 'from the point of view of the author's or editor's intent, the unified results, and how it would be perceived by an audience or near contemporaries" (Kennedy, 1984:4). Rhetorical analysis as described in this study, therefore, investigates the biblical art of persuasion that seeks to reveal the mutual relationship of the author(s), the text, and the readers/hearers (Gitay, 1993:136).

The study of the aspect of the reader can be associated with reception theory (or readerresponse theory) as well. There is, however, a significant difference between reception theory and rhetorical analysis as described in this study. Receptionists focus on the act of reading and the audience's imagination and self-interpretation. In reception theory the reader must actualize the meaning that is only potential in the text. Most reception theories hold that a text means nothing until someone means something by it. More radical proponents of 
reception theory go further to say that the reader creates the meaning of the text (see Tate, 1991:xix). Rhetorical analysis, on the contrary, studies the attempt of the author to bring the audience/readers into agreement with his intention by means of the text's persuasion. In this regard, some practitioners of reception theory, like McKnight (1985:128), even hold a similar opinion that meaning is produced by the mutual interaction between the text and the reader. Thus, the analysis of rhetoric in this study focuses on the text itself, regarding the audience/readers as an element in the deliberate communicative endeavour and not as a mere subjective commentator.

Classical rhetoric consisted of five parts that recapitulated five stages in the act of composing a speech (see Trible, 1994:7-9). The five parts of rhetoric are invention, which deals with the planning of a discourse and the arguments to be used in it; arrangement, the composition of the various parts into an effective whole; style, which involves both choice of words and the composition of words into sentences, including the use of figures; memory, or preparation for delivery; and delivery, the rules for control of the voice and the use of gestures (see Kennedy, 1984:13-14).

Based on these five parts of rhetorical analysis, in this study, a study of the rhetorical aspects of Psalm 78, which correspond to invention, arrangement, and style in classical rhetoric, will be explored next. Following that, the rhetorical goal and persuasive intention in Psalm 78, which correspond to memory and delivery in classical rhetoric, will be discussed.

\section{Rhetorical Aspects of Psalm 78}

As stated above, rhetorical analysis takes the text as we have it, and looks at it from the point of view of the author's intent, the unified results, and how it would be perceived by the audience/readers of near contemporaries. Likewise, the psalmist of Psalm 78 compels the attention of his audience/readers by employing the quasi-logical argument of comparison, which is an effective rhetorical means of persuasion, described in the classical handbook on rhetoric, known as Ad Herennium (Cicero, 1954:IV.59): "It is, moreover, presented in the form of a contrast. For a comparison in the form of a contrast is used when we deny that something else is like the thing we are asserting to be true. ... Thus the comparison is used for the purpose of proof." The two-dimensional parallel figure of Psalm 78's structure produces this quasi-logical argument of comparison. By focussing on successive episodes, the audience/readers are expected to compare a series of "divine deeds of grace" on the one hand, and "a similarly continuous series of examples of disobedience and punishment as a warning" on the other. With this comparison, the psalmist seeks to prove God's everlasting faithfulness in spite of Israel's total infidelity.

Based on this dominant rhetorical feature, which reflects the speaker's (author's) major purpose in speaking or writing, the psalmist develops several rhetorical devices to appeal to the audience/readers.

The use of the first person pronominal suffix in verse 1, עמי (my people,) and תורתי (my teaching) instead of the abstract noun עורה (people) (teaching or regulation) intends to strengthen the tension in this passage. It reveals a specific intentional stylistic device of rhetoric. It is claimed by the psalmist as his own teaching, given by him to his people in the frame of parallelism. This rhetorical device points out the absurdity of the people's actions - those whom God personally brought up and led with covenantal love did not keep the covenant of God, his Torah (verse 4).

The psalmist continues in the first person singular describing his teaching in the language of wisdom, as a wisdom saying (משל)), and riddles (חידות). Here, the use of the term 
"riddles" also embellishes the psalm's rhetorical effects since riddle can be defined as an enigmatic proposition since the purpose of the riddler is to confuse his/her audience by exploiting an unexpected relation between the descriptions of the subject and its answer (see Perdue, 1974:533-534). The audience/readers should pay close attention because the psalmist warns his teaching will be presented not in a straightforward manner but rather in a puzzling or mysterious form, namely in "riddles." In composing his message, the psalmist recounts events in Israel's common national history: the Exodus, the wilderness experience, the settlement in Canaan, the destruction of the Shiloh shrine, and the establishing of the temple site by David. In this connection Yahweh's gracious history itself is truly full of "riddles," since Psalm 78 deals with the paradox of Israel's total inability to trust God's praiseworthy deeds of deliverance, despite the long-continued and repeated nature of those acts. Israel's existence in the world of the nations and the course that Israel follows are also a great mystery. Yahweh creates a space for his people and for their history. He drives out nations before them (verse 55) only for the sake of Israel.

When the psalmist of Psalm 78 describes Yahweh's gracious history, he avoids abstraction because a common perspective shared by the speaker/author and the audience/readers is essential for effective rhetorical communication (Gitay, 1993:137). The psalmist begins with specific events that God performed before the eyes of audience's/ readers' fathers (verse 12), and that they have heard and known because their fathers have told them (verse 3). Especially, in the second stanza of the second recital (verses 43-55), ${ }^{2}$ the praiseworthy deeds of Yahweh are largely described in the form of a more detailed catalogue. Even here, when the psalmist recounts the plague account, his using different accounts with regard to the sequence as well as the wording from other passages of the Old Testament does make rhetorical sense. In the psalm the plagues begin with an assault on Egypt's water (blood) and its land and vegetation (flies, frogs, grasshopper, locust, hail, and frost), then they escalate in severity by attacking its livestock (hail on the cattle and thunderbolts) and its people (killing the first born). From this firm historical ground, the speaker/author and the audience/readers can share an agreement of Yahweh's gracious history, not only for their fathers but also for themselves in the present.

After the psalmist has established a common perspective of Yahweh's gracious deeds, he then dramatically turns to the disputable issue of Yahweh's rejection of Israel (verses 5960 ). This is no mathematical proof, but a sound quasi-logical argument that draws its conclusion based on the principle of cause and effect. The psalmist's concept of God's punishment, based on his religious thesis of cause and effect, is founded on the law of nature that rejects the incidental: ex nihilo nihil fit (nothing comes from nothing). The psalmist accuses the Israelites of their sin. Because of the people's total infidelity and repetitive rebellion, Yahweh utterly rejects Israel (verses 40-41).

The psalmist also uses several metaphors as a style (elocutio) of rhetoric, which involves both choice of words and the composition of words into sentences, including the use of figures of speech (cf. Kennedy, 1984:13-14; Trible, 1994:8-9). In Psalm 78, Yahweh is called their rock by the people of God (verse 35). This metaphor clearly depicts Yahweh as the one who shelters and protects. Likewise, when it is said that Yahweh sleeps, it is also a metaphor that expresses the hidden nature of Israel's God (verse 65). Yahweh is the living God. He hears and answers (verse 21). He saves, helps, rescues and delivers from trouble and the pangs of death (verse 66). The metaphor of shepherd and flock also describes the intimate relationship between Yahweh and his people (verse 52; cf. Kraus, 1986:53). By

For a detailed analysis of the structure of Psalm 78, see Kim and Van Rooy, 2000:287-289. 
using such metaphors, the psalmist characterizes the intimate relationship between Yahweh and his people, based on Yahweh's lordship, in order to persuade the people of God to remember and to retain this solemn relationship. Israel must acknowledge, praise, and proclaim the fact that Yahweh's lordship has shown itself as a liberating, saving, and helping power. Yahweh himself and his name are symbols of liberation and deliverance, according to Kraus (1986:31), the prototype of which is the choosing of Israel and Israel's liberation out of bondage in Egypt (verse 12).

The use of rhetorical questions is another important tool in speech because it is one of the most forceful and effective ways employed in speech for driving home some idea of conviction (Labuschagne, 1966:23). In Psalm 78 the device of the rhetorical question is also used significantly and purposely, for example in verses 19-20. These rhetorical questions offer a striking contrast to verse 7 , that they would put their confidence in God... and it clearly shows the difference between scepticism and simple trust.

Rhetorical analysis traditionally differentiates three types of oratory: viz. forensic (legal), deliberative (political), and epideictic (ceremonial) (Aristotle, 1926:1358b; cf. Trible, 1994:8-9; Kennedy, 1984:19). Concerning the rhetorical type, the type of Psalm 78 seems to be a mixture of all three types. It is involved with the time sequence of all three, the past, the present, and the future. In this way, the psalmist tries to utter the praiseworthy deeds of Yahweh from of old through the present audience/readers and to the generation to come, so that they would put their confidence in God, and forget not the works of God (verses 7-8). Such a mixture of types requires special attention to the crucial question of the nature of rhetorical speech (cf. Gitay, 1993:140).

With these rhetorical devices, especially a mixture of types, and the use of rhetorical terms such as משל חידות (wise saying) andles), the psalmist seeks to educate his audience/readers. In this regard, the rhetorical goal of the communication in Psalm 78 seems to be an intellectual goal of teaching (see Trible, 1994:89). The goal of the psalm is to edify the people by an orator/author who can authoritatively restate the ancient traditions, through the recollection of a shared history, so that the people will choose Yahweh. In the efficacy of remembering by invoking the past as a motivation, the psalmist seeks to persuade the people to maintain their side of the covenant. The use of memory that stimulates positive action prompts people to change direction. This rhetorical goal, "remember!" will now be discussed in the following section.

\section{The Rhetorical Goal of Psalm 78}

In classical rhetoric, the goals of communication were directed at the audience/ readers usually in three ways: viz. the intellectual goal of teaching, the emotional goal of touching the feelings, and the aesthetic goal of pleasing in order to capture and maintain attention (Trible, 1994:8).

Likewise, the psalmist of Psalm 78 seeks the best way to accomplish his goal of divine persuasion. To achieve his goal, the psalmist does not exhort his audience directly, in the style of Deuteronomy 7:18-19. Instead, the force of Psalm 78's rhetoric is to edify his people by example. In Psalm 78 the speaker does not command his audience/readers to recall their common traditions and the role of their God therein. In recounting the history of Israel, the psalmist, according to Greenstein (1990:201-202), sets a model of remembering by engaging himself in a sophisticated exercise of remembrance. He performs this exercise by means of two rhetorical strategies of remembering: viz. 1) the people of God should remember the praiseworthy deeds of Yahweh, and 2) Yahweh remembers his covenant. 


\subsection{Remember the Praiseworthy Deeds of Yahweh!}

To facilitate the people's remembering of the praiseworthy deeds of Yahweh, the psalmist of Psalm 78 repeatedly evokes the familiar language of common traditions. By referring to historical events, the psalm reverberates with the vocabulary and details of the primary narrative (that is, perhaps, as narrated in the Pentateuch). The psalmist appears to make continued reference to the primary narrative in calling attention to the covenantal history. $\mathrm{He}$ takes the audience/readers through the Exodus and wilderness experience. He then performs the most unusual turn of going further back in the collective remembrance by retelling the history of redemption. He begins his recapitulation with the actual Exodus, following the plagues. At a certain point in his wise saying (משל), he goes back even further in his recollection than the initial starting point of his account. The psalmist only strains to remember by going farther back when his story explicitly and ingeniously takes up the theme of remembrance (cf. Greenstein, 1990: 208-209).

In spite of God performing wonders in the land of Egypt and in the wilderness, and feeding them, the people of Yahweh returned to God only when he threatened to slay them (verse 34). Then, the psalmist says, and they remembered (1רזי! that God is their rock... and redeemer. They still were not sincere, but God forgave them. He remembered (רי? verse 39): He remembered that they are flesh, a wind that passes and comes not again. Yet, the Israelites tested God again. They failed to remember (לאיזכיזרוּ, verse 42) his powerful hand by which he delivered them from Egypt. As a remedy for the people's chronic forgetfulness, the psalmist takes special pains to recall the more remote past for them. He leads them on a journey of remembrance by taking them back before the Exodus, to the plagues and the staggering wonders that God had wrought then. At that moment, the psalmist raises memory as a positive theme, using the term three times in succession, to exemplify his theme through a rhetorical act of remembering (Greenstein, 1990:208-209).

In this respect, it must be noted that for neither God nor Israel, there is a sharp discontinuity between the past and the present. As Childs (1962:42) presents it, "God's memory is not a re-creating of the past, but a continuation of the selfsame purpose. ... His memory includes both the great deeds of the past as well as his continual concern for his people in the future." In Psalm 78 the continuity between the past covenantal history and the present becomes clear through the intellectual goal of rhetorical teaching. When the people of Israel are taught their covenantal history by the teaching of the psalmist in a form of wise saying (or riddle song), they should remember what Yahweh once did in the land of Egypt and in the wilderness. They must not forget that Yahweh has led them from Egypt to the Promised Land in spite of their repeated infidelity. The people of Israel should remember that they acted as a stubborn and rebellious people in the past. While there is no attempt to reform past history, Israel's remembrance does serve a far more important role than merely providing illustrations from the past (Hyde, 1988:410). They should acknowledge the fact that Yahweh will do so again for the sake of Israel in the future.

In this regard, the rhetorical goal of Israel's remembering of God's deeds functions in an analogous way (see Hyde, 1988:410). On the one hand, the people's remembering of God's praiseworthy deeds serves as the motive for praise and thanksgiving, and enables each new generation to appropriate the Heilsgeschichte. On the other, the remembrance of the past, and in particular Israel's sins and infidelity, is a call for the people to act, to change their behaviour by means of keeping the covenant of Yahweh, his Torah (verse 10).

The question of how the historical events are remembered in Israel is also important, since delivery (pronunciatio or actio) plays an important role of classical rhetoric (Aris- 
totle, 1926:1404a). In classical rhetoric delivery concentrated on the aspects of presentation appropriate to the subject and the style (Trible, 1994:8). In the Psalms as Israel's sacred poetry, delivery takes the form of "re-presentation" or "actualization (Vergegenwartigung)."

According to Hyde (1988:410-411), there are two distinct schools of thought that may be roughly described as the cultic and the historical. The cultic approach, exemplified by Mowinckel and Weiser, regards the locus of "re-presentation" as a liturgical/cultic action. The Heilsgeschichte is "acted out," as it were, in a dramatic and symbolic manner. For Weiser (1962:470), such a cultic act was "understood as a present action of God directed toward the members of the cult community themselves and causing all historical differences of space and time to disappear in face of the reality of God." Those who follow the historical approach react to the "mythological elements" in the cultic view and maintain the once-and-for-all character of the past. Time is not annihilated by remembrance, and the past remains the past, although it is deeply significant for the present. Westermann draws a parallel between this remembrance-by-recitation with the "historical credos" of the Pentateuchal and Deuteronomic traditions (Westermann, 1981:228-235).

There are also some scholars who take a middle position. They assert that "mythological" thinking is alien to Israel's remembering, but they want to stress that remembrance is more than recitation. They call for an understanding of remembrance that is focused on the timelessness of God who is always encountered by Israel, both in history and in the cult. Among those, especially Noth's opinion seems to be the most valid and comprehensive one: “'Re-presentation' is founded on this - that God and his actions are always present, while man in his inevitable temporality cannot grasp this presentness except by 'representing' the action of God over and over again in his worship" (Noth, 1963:85).

In Psalm 78, likewise, God and his praiseworthy deeds are recalled as a motive for the people's praise of their God. Indeed, this is the heart of the relationship between Yahweh and Israel, not only in Psalm 78 but also in whole Psalter because whenever the Psalms speak of Israel's beginnings or of the beginnings of Yahweh's coming to Israel, we find the theme of the Exodus, the praiseworthy deeds of Yahweh (Kraus, 1986:51). Yahweh is the only God worthy of praise, and Israel is the people whose special vocation, of all the peoples of the earth, is to praise this gracious, steadfast, and loving God. In appeal, confession, but above all in praise, the reasons are therefore to be found for Israel's continual remembrance of the praiseworthy deeds of Yahweh in which Yahweh is manifested, and by which the people have been brought into being (cf. Hyde, 1988:411).

\subsection{God Remembers His Covenant (ברית)}

According to Childs (1962:41), the chief object of Israel's praise centres on Yahweh's faithfulness in remembering his covenant (ברית). "He has remembered his covenant forever" (Psalm 105:8; cf. Psalms 106:45; 111:5). He has manifested covenantal loyalty toward Israel (Psalms 98:3; 106:45; and 136:23). Psalm 105:8 and 42 view Israel's entire redemptive history as the result of God's remembering of his covenant.

However, still the troubling question remains: On which basis does God remember his covenant? This question seems to be related to the question of the semantic field of the word ברית. In fact, there is no unanimity among scholars about the semantic field of this word. The divergence of opinion on this word is summarized in a question by Van Rooy (1982:93): "Does ברית refer only to obligations, or does its semantic field include the element of a relationship between different parties?" Likewise a question can be asked about the basis of God's remembering his covenant: "Does God remember his covenant based on 
his self-obligation to love his people, or does God remember his covenant based on a relationship between God and his people?"

For Kutsch (1997:258-259) the answer is God's self-obligation because he argues that is nowhere employed in the sense of an agreement (Bund) between Yahweh and Israel, but only of either Yahweh's self-obligation, that is, his promise to another, or an obligation imposed by Yahweh upon another. On the contrary, Weinfeld explains the semantic field of the word ברית somewhat differently. For Weinfeld (1975:255-256), ברית originally implies the notion of "imposition," "liability," or "obligation," but gradually it becomes to be used for the idea of a covenant. Then, the terms for covenant are distributed according to two semantic fields: Oath and commitment on the one hand, love and friendship on the other. The settlement of covenantal relationship between two parties is conditioned by goodwill or some kind of mutual understanding which enables the conclusion of an agreement, and this is why covenantal relations are expressed by terms like "grace," "brotherhood," "peace," "love," and "friendship" (Weinfeld, 1975: 257).

The use of בn Jeremiah 11 also clearly shows this term to designate the special relationship between Yahweh and his people since the and the relationship are indissolubly linked in Jeremiah 11 (see Van Rooy, 1982:93-102). The making of the ברית initiates the relationship and the breaking of the ברית terminates it. Keeping the continuation of the relationship and the assurance of blessing, and breaking the ברית terminates the relationship and the blessings become curses. In this respect, the word ברית can be regarded as a compound term that refers to obligation and relationship with interdependent commitment and friendship. When God remembers his covenant, he remembers his selfobligation to love his people on the one hand, and (at the same time) he remembers the covenantal relationship between himself and his people on the other.

In this regard, ברית in verse 10 is seen primarily as an obligation which the people were compelled to keep, but they refused it. Likewise, ברית in verse 37 can be seen as an obligation with commitment to which the people should be faithful but they were not. As far as the interdependent concept between obligation and relationship is concerned, however, both verses 10 and 37 seem to state that the people broke the covenantal relationship that existed between Yahweh and the people of Israel because not keeping the covenant (ברית) terminates the relationship. The mutual covenantal relationship was indeed broken by Israel when they did not keep the covenant of God and they refused to walk in his Torah (verse 10), when they were not faithful to Yahweh's covenant (verse 37). In that case, God punished his rebellious people by rejecting them with divine fury (verse 59).

Nevertheless, it does not mean that the covenant, the circle, is broken by God. Even if he rejected Israel for some time, it does not mean that Israel was totally rejected. Israel was never rejected absolutely, a conception which is found among the ancient Orientals, e.g., the Babylonians, who in their Creation-narratives suppose that the wrath of the gods had in view the complete destruction of mankind (see Walton, 1989:236-247). In Psalm 78, we can find the "further" election of Jerusalem. This implies the continuous faithfulness of the electing God, rather than the possibility of definite rejection by God of what he has once elected through his covenantal love. Rejection is a judgment based on the inconvertibility of man, and it is never founded on the unwillingness of God, because he remembers his covenant forever (see Vriezen, 1958:142). Psalm 78 can therefore be viewed as Yahweh's covenantal loyalty where he remembers the covenantal relationship according to his covenant (verse 37) and his selfobligation to love his people in spite of their breaking of the covenantal relationship and unfaithfulness to their covenantal obligation (verses 39 and 10). 
In this connection, Yahweh's constant willingness to overlook Israel's betrayal of the covenant (ברית) can be clearly found in Psalm 78. This carries an implication of a possible meaning of the term חסח. In the Old Testament, according to Johnson (1979: 65), the keeping of a covenant was indicated by means of the expression חסד ואמת, which conveys the thought of what we understand by true devotion. These two terms basically taken together in this way, denote the loyalty (7סח) to which one commits oneself by a sworn undertaking or pledge of truth (אמת) as the basic requirement for carrying out the responsibilities accepted under such a covenant in Psalm 78. Accordingly, although the term 7on does not occur in the psalm, such a contrast between Israel's repeated unwillingness to remain faithful (אמן) to its undertaking of Yahweh's covenant and, on the other hand, Yahweh's persistent compassion (רחם) can be detected throughout the entire psalm. Thus, it is quite clear that the everlasting faithfulness of God in Psalm 78 is deeply rooted in his covenantal love. In spite of the people's continuous rebellion, God is always faithful to his covenant. Yahweh's consequent endeavour to preserve the covenantal relationship and to continue on his own with this rebellious people, may well go far to explain Yahweh's faithful remembering of his covenantal love (cf. Johnson, 1979:65-66).

As far as this loyal devotion (חסד ואנת) of Yahweh to his covenant (ברית) is concerned, it is significant to observe that the object of God's remembrance cannot be consistently confined to the past. The praiseworthy deeds of the covenant continue to meet Israel in her present situation. Actualization is the process by which a past event is contemporized for a generation who is removed in time and space from the original event (Childs, 1962:85). When the audience/readers of Psalm 78 respond to the continuing imperative of Yahweh's Torah through their remembrance, that moment in historical time likewise becomes an Exodus experience.

Therefore in Psalm 78, the covenant plays a significant role both because of God's remembering of his covenantal people, and because of the people's remembering of God's covenant. Israel should put their confidence in God's covenantal love, and not forget the works of God, but keep his commandments, because he is so compassionate to remember his covenant. Remembering, both God's remembering of his covenant and the people's remembering of God's covenantal love, is the most important goal of the psalmist. "Remember!" because forgetting God's covenant in the present means giving up hope for the future (see Brueggemann, 1995:178).

\section{Rhetorical Persuasion in Psalm 78}

When we apply the framework of classical rhetoric to the biblical text, we must be cautious about the distinctive character of the Bible. Most modern critics recognize that there is a distinctive rhetoric of religion, and at the heart of it lies authoritative proclamation, not rational persuasion (Kennedy, 1984:6). The divine orator of Israel, however, can be regarded as a persuasive vehicle of God's will to whom God supplies the necessary words, and his audience is persuaded, or not persuaded, not because of the capacities of their minds to understand the message, but because of God's love for them which allows their hearts to be moved, or withholds that grace (see Kennedy, 1984:6-8). In this respect, an investigation of the persuasive function in Psalm 78 according to the framework of classical rhetoric can be helpful to clarify the divine will, namely the divine rhetorical revelation in the psalm.

Rhetorical analysis understands communication to be an exchange between the orator/speaker and the audience (the author and the reader if communication is written) by means of the medium (text). The speaker/author initiates and seeks to manage this ex- 
change, to move the audience/reader to think and to act in a particular way. The Old Testament depicts numerous such exchanges between God and individuals or groups. Divine rhetorical revelation can, therefore, be regarded as describing the rhetorical dynamics of these exchanges (see Patrick, 1994:21-22).

As stated above, there are three types of oratory in the classical rhetoric, viz. forensic, deliberative, and epideictic. Each type has a particular focus, setting, purpose, time, and emphasis (see Trible, 1994:8-9). With the time sequence, all these three types of oratory seem to be relevant to the persuasive function of Psalm 78. Like the orator of forensic discourse in the classical rhetoric, the psalmist of Psalm 78 seeks to persuade his audience/readers to make a judgment about events which occurred in the past, that is, a judgment between the faithfulness of God and the total infidelity of the people. The psalmist also persuades the people to hold or reaffirm some point of view in the present, that is, to remember the praiseworthy deeds of Yahweh and his covenant, like epideictic discourse. Furthermore, like deliberative discourse, the psalmist persuades the people to take some action in the future, that is, to put their confidence in God like David, a person who set his heart aright to God and whose spirit was faithful to God.

\title{
5.1 David as a Persuasive Model in Psalm 78
}

David is the dominant figure in Israel's narrative and poetry (see Brueggemann, 1985:13; Deist et al 1982:4, 92). The study of the place of David in the Psalms suggests that there is a David whose reality and importance lie in his connection with psalms and psalmody (see Mays, 1994a:87-90). In Psalm 78, as David receives a new promise from God in the narrative cycles, God makes his choice of Judah and sets a new beginning with David as king, and the Jerusalem temple as his sanctuary. In verse 67, God rejected the tent of Joseph, that is, the Northern sanctuary, and the tribe of Ephraim he did not choose. This is different from the rejection of verse 59. When God utterly rejected Israel with the fall of Shiloh, he punished the whole people and removed himself from all of Israel for a period. Now, however, he denies only the tent of Joseph and the tribe of Ephraim, and chooses, instead, Zion and the tribes of Judah, upon which God bestows the Davidic monarchy. The emphasis in this passage is not upon the rejection of the Northern tribes (see Clifford, 1981:137), but the issue is Yahweh's chosen sanctuary and his establishment of the Davidic kingship. The chiastic arrangement in verses 67 and 68 shows it clearly:

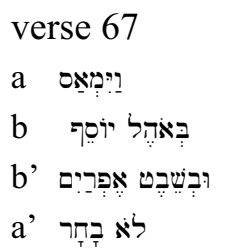

\begin{tabular}{|c|c|}
\hline & verse o8 \\
\hline and he rejected & a רַיְבְחָרר \\
\hline the tent of Joseph, & b את-שֶבֶט יְהוּדָה \\
\hline and the tribe of Ephraim & 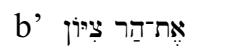 \\
\hline he did not choose. & a' אֶשֶר אָהבב \\
\hline
\end{tabular}

\author{
but he chose \\ the tribe of Judah, \\ Mount Zion, \\ which he loved.
}

God himself caused the rejection of his people, and of his own choice, he did not choose the tent of Joseph and the tribe of Ephraim. The psalm, however, does not end on this doleful note. Rather, it tells how God once again roused himself and acted on behalf of his people. It is with this that the psalm reaches its climax: God's choice of Mount Zion as his new and permanent dwelling place, and his election of David as king (Bright, 1977:62). Installing the sanctuary of Yahweh's presence with Israel in the new capital served to establish David's regime, but the most precious emblem of God's presence with Israel was David himself, the king chosen by God (Tate, 1990:295). David moved from being a shepherd of sheep to being a shepherd of God's people because his heart was aright to God. It contrasts 
well with the past generation who did not set its heart aright to God. The use of the term heart (לבב or) in verses 8b, 18 and 37 clearly shows that the heart of the past generation is regarded as a negative example of what the audience/readers should not be like. On the contrary, only in the last occurrence of this term heart (verse 72) we find David's heart (לבבו) perfect in its condition. In this respect, the role of David in Psalm 78 can be regarded as a persuasive model that can persuade the people to take some right action in the future. In fact, whenever a speaker effects persuasion through proofs, he does so either with examples or enthymemes in classical rhetoric (Aristotle, 1926:1356b). In Psalm 78, the present generation is directed to keep the covenant of God and to walk in the Torah of Yahweh. The people need some excellent positive example to be followed. In Psalm 78 God shows them the person of David as that model. When David is called the servant of Yahweh (verse 70) he is accorded a place of honour and a role of service since those who belong to Yahweh are his servants (Kraus, 1986:157). The sudden ending of the psalm also clearly exhibits this persuasive purpose. With the presentation of David, the psalmist's intention reaches its climax. Remember the person of David! Set your heart aright to God! Be steadfast to God and be faithful in his covenant, like David who had integrity of heart toward God!

In addition, the canonical shape of the Psalter supports this magnificent role of David as well. After a careful investigation of the use of the royal psalms in the Psalter, Wilson (1997:79) comments on the theme of the royal psalms. The covenant Yahweh made with David (Psalm 2) serves as the source of David's assurance (Psalm 41), and is passed on to his descendants in the series of petitions on behalf of "the king's son" (Psalm 72). These petitions for God's blessing are not only predicated on the basis of Yahweh's covenant obligation, but also on David's proper action on behalf of his people. In this regard, Book III of the Psalter departs strongly from the Davidic motif that dominates Books I and II. The end of Book III, Psalm 89, especially verses 3-4, also returns explicitly to the theme of the Davidic covenant introduced in Psalm 2. Thus, the first three Books of the Psalter reflect the hopes about the Davidic monarchy based on the covenant of David. In Psalm 78, this hope also manifests the faithfulness of Yahweh to his covenantal promises, and a plea for the new beginning (cf. Wilson, 1997:82).

David was indeed a man after God's own heart. As for the people chosen by God, David guided them with his skillful hands (verse 72). All this was because he did not forsake God, nor was he ever guilty of ingratitude toward God - unlike the past generation. Therefore, the people of God should remember the covenant of God and walk in the Torah of Yahweh as David did.

\subsection{Divine Rhetorical Revelation in Psalm 78}

According to Kraus (1986:51), whenever Yahweh speaks to the people to whom he has made himself accessible, to whom he has communicated and revealed himself, he makes his appearance as the Holy One of Israel (קדוש ישראל, verse 41). In the term Holy One of Israel, Yahweh's dwelling among his people is emphasized. The personal name of God, Yahweh, in Psalm 78 also represents the assurance of the effectiveness of Yahweh's presence among his people; it is the gift and guarantee of God's call (see Richards, 1985:415418; Kraus, 1986:52-53). Under the sign of his name, that is, his self-disclosure, Yahweh made his gracious will known to his people. He has established his testimony (עדות) in Israel (verse 5).

In Psalm 78, through the event of the Exodus and the experience of the wilderness Israel became Yahweh's sanctuary (קדש, verses 54 and 69). As Yahweh's sanctuary the people of 
God are the context in which God reveals himself and where his people give him their willing, obedient service in time and space (Kraus, 1986:52). In this respect, it is also important that Yahweh reveals himself in the history of his acts. As in the past, he still makes himself known through the praiseworthy deeds of Yahweh (תהלות יהוה, verse 4) and in his wonders (פלאות, verse 4). In the sight of the Israelites Yahweh performed a wonder (verse 12), but they "forgot" the praiseworthy deeds that had been done in their midst. The Israelites "did not believe" in his wonders (verse 32). In this regard, it is Yahweh's deeds in history that form the basis of the people's life. In the historical events, he intervened fully in favour of his people. In the Old Testament, thus, history is that which it is and that to which it bears witness solely and entirely by virtue of the subject who acts in it. In Psalm 78, the praiseworthy deeds of Yahweh are those to which Israel constantly relates itself and on which Israel's life is based. In all these testimonies to history there is no doubt even for a moment that God's people should not rely on themselves, on their faith, on their accomplishments, but on Yahweh alone (Kraus, 1986:60). They would put their confidence in God ... (verse 7).

However, the historical perspectives that open up before us in Psalm 78 make it all too clear that Israel was not a pious people, obediently following Yahweh. They were always open to faithlessness and rebellion against Yahweh. How lightly the Israelites forgot their God, and "turned back and acted treacherously like their fathers" (verse 57). That Israel "still sinned and did not believe in his wonders" (verse 32) is the shocking fact of their history. Therefore Yahweh's wrath rose against his people (verses 21 and 31) and he utterly rejected them (verse 59). It clearly shows that Israel was not an already-existing entity, but always had to receive its identity anew from Yahweh, and ever to be brought into being by him (see Kraus, 1986:61).

This mutual character of Israel's history is, indeed, a mystery between God and his people. In Psalm 78, Yahweh reveals this mystery in a form of wise saying (משל), which speaks of riddles (חידות) from of old (verse 2). These riddles are the mysteries of God's saving work in Israel's history, and of Israel's behaviour. It is the "story" which sets forth "the mysterious conflict between the power of God and the power of sin" (Weiser, 1962:541). The psalm deals with sorrowful stories of the infidelity of Yahweh's own people, disobedience, and of the consequences which followed. "At the same time," however, "it is meant to warm the heart, for it tells of great miracles, of a grace that persists through all the judgments, and of the promise that displays its tokens in the chosen city and chosen king" (Kidner, 1975:280). These gracious acts of Yahweh are in a certain sense "irrational," as Weiser (1962:538) points out, there is an "irrational quality about the things that have come to pass" in Israel's history. These are the riddles at the heart of the wise saying out of which the Israelites lived and out of which we should live (see Tate, 1990:295-296).

So Yahweh's praiseworthy deeds and wonders, mentioned in Psalm 78, are not mere historical retrospect, but an "interpretation of history" (Sabourin, 1969:302), namely that Yahweh has caused his wonderful deeds, to be remembered as a revelation of Yahweh in the history. In them Israel commemorates everything that Yahweh has done, and that has supported and determined the life and being of the people of God. For this reason, in Psalm 78 , Yahweh's praiseworthy deeds and his wonders must be told to every new generation, so that they may learn its lessons and worship its Lord. Moreover, God himself commands his praiseworthy deeds to be passed from generation to generation. So, the structure of the memoria is established by this looking back at the redemptive history. Israel, as the people of Yahweh, should remember Yahweh's praiseworthy deeds and his covenant, which in this remembrance become present reality. For the people of Yahweh, God's way and will are essential elements of reality (see Mays, 1994b:225). 


\section{Conclusion of the Dimension of the Reader in Psalm $\mathbf{7 8}$}

In conclusion, it becomes clear that the intention of the psalm emerges from a reading of the dimension of the reader, especially through the rhetorical analysis utilized as a reading strategy in this study. Various rhetorical aspects such as the quasi-logical argument of comparison, some intentional stylistic devices, several metaphors and rhetorical questions are all employed in this psalm in order to bring the audience/readers into agreement with the intention of the psalmist. The rhetorical type of Psalm 78 seems to be a mixture of all three types of oratory: viz. forensic, deliberative, and epideictic. This mixture of types is interwoven with the time sequence of past, present, and future in the psalm. In the efficacy of remembering by invoking the past as a motivation, the psalmist seeks to persuade the people to maintain their side of the covenant in the present. At the same time, the role of David in Psalm 78 can be seen as a persuasive model for the people to take some right action in the future. Therefore, the psalm as a process of remembering does not ruminate upon the past, but it addresses the present and, like the prophets of Israel, seeks to transform the future. In this whole time sequence of the remembering process, Yahweh himself has caused the people to remember his praiseworthy deeds and wonders as his revelation in history. In this respect, the intention of the psalm is not to be a mere historical condemnation, but it is, as Kroll (1987:219) defines it, "a philosophy of history" designed to benefit Israel in the present with the purpose of changing it. The psalmist practices memory, not to recount the past, but to prompt the kind of remembrance that leads to change in the present. The rhetorical goal of Psalm 78, then, can be seen as an intellectual goal of teaching. The objective of the psalm is to edify the people by an authoritative restatement of the ancient traditions from the past, through the recollection of a shared history in the present, so that the people will decide for Yahweh in the future.

\section{Concluding Remark on a Multidimensional Reading of Psalm 78}

As stated in the first article of this series (see Kim and Van Rooy, 2000:285-286), accepting the principle of a pluralism of exegetical methodologies is a methodological presupposition for this study. Based on this presupposition, various exegetical methods that elucidate the meaning of the psalm have been employed in this study. As basis for this plurality of exegetical methodologies, the communication model has been adapted as hermeneutical framework. As a result, the three basic elements of the communication process (the sender, the medium, and the receiver) constitute the model of this multidimensional reading of Psalm 78.

For the reading of the communication process of Psalm 78, each dimension has been described synchronically as well as diachronically. Although various studies have pointed out the importance of distinguishing between synchrony and diachrony, ${ }^{3}$ it emerges from this study that these are not mutually exclusive categories but they are equally important to open up the meaning of the text of the psalm (see Jonker, 1998:4). In fact, the synchronic and the diachronic aspects of every dimension have brought helpful and deeper insight in the psalm.

The reading of the diachronic aspects of the textual dimension has provided good insight to establish a reliable basis for interpretation, viz. the textual-critical study of the same diachronic aspects. Likewise, the reading of the synchronic aspects of the textual dimension, based on the various synchronic exegetical methodologies, such as linguistic analysis, structural analysis, and genre analysis, clarified the structure and genre of the psalm. .

For the reading of the authorial dimension, the synchronic aspects have been studied

For more recent discussions of "synchronic or diachronic," see De Moor, ed., 1995. 
from the historical and religious components of the psalm, while the study of the diachronic aspects focused on the text's background. Based on the mutual relationship between diachronic and synchronic aspects, the investigation of the heading, of the tradition history, of the dating and the historical setting (with Sitz im Leben), and the study of the canonical shape of Psalm 78 have all contributed to yield some new and fresh insight for understanding the psalm's own genesis.

For the reading of the dimension of the reader, diachronic aspects and synchronic aspects have been investigated by means of rhetorical analysis. In particular the study of the rhetorical devices, the rhetorical goal and the rhetorical persuasion have clearly elucidated the intention (aim) and message of the psalm.

In addition, the constant interaction among the different elements of the communication process has been taken into consideration in this study. For the interaction between the sender (the author) and the medium (the text), the synchronic aspect of the authorial dimension provided the basis for the description. The interaction between the medium (the text) and the receiver (the reader) is also analogous to the interaction between the sender (the author) and the medium (the text), so that the synchronic aspect of the reader provided the basis for the interaction between the medium (the text) and the receiver (the reader). Each level of interaction can be situated in a specific context, and this specific context constitutes the specific worldview of the psalm.

From all of these methodological concerns it has become clear that the textual dimension should be regarded as the meeting point of the communication process. Lategan (1992:153) agrees with this point, when he says that "in its written form, it (the text) is the static record of a preceding event of understanding, and its text-immanent features are important clues for its interpretation." The textual dimension is thus both the beginning of the process of the interpretation and the end of the process of the production of the meaning.

In this multidimensional reading, every exegetical aspect based on the communication process has brought new and helpful insights. Not only does each method bring its own intention to the text, but each also complements and informs subsequent one(s). The methods, thus, assume more significant proportions when viewed together than when considered in isolation. At the same time, the synchronic and diachronic aspects of all the dimensions and the interaction between them also bring broad and (at the same time) balanced perspectives to the understanding of the psalm.

Consequently, a multidimensional reading of all the exegetical aspects based on the communication process is seen as having great value in order to obtain a more valid meaning of the text. However, it does not mean that this study can provide the final answer to the dilemma of exclusivity within diversity in the exegetical praxis. Rather, this multidimensional reading of Psalm 78 can only provide a direction in which the discussion should develop (cf. Jonker, ca1996:332). Moreover, all the proposed methodologies mentioned in this series of study would not be relevant to the understanding of all the Psalms. For instance, the study of the heading of the psalm or the study of the tradition history of the psalm cannot be relevant to some psalms which do not have their own headings or traditional-historical components. The reading of every psalm, thus, needs its own multidimensional exegetical approach.

\section{Prospect}

A multidimensional exegetical approach can contribute to the church's preaching since every preacher should also be an exegete of the Bible, although every exegete does not necessarily become a preacher. Moreover, understanding the communication process of a text 
multidimensionally not only helps a preacher's understanding of the text, but also gives good insight in the text's own interaction between the orator (the author), the medium (the text), and the audience (the reader). In the same way the multidimensional reading of a biblical text can also contribute to the church's understanding of the Bible. In fact, those readers who are aware of the communication process of the biblical text, are in a better position to understand its message more accurately than those who are not.

Jonker (1998:6-9) distinguishes two kinds of multidimensional reading, namely specialized reading and competent reading. While specialized reading takes place at the hand of a given set of methodological presuppositions and specialized methods, competent reading is a relevant method to fairly experienced readers who have developed a degree of skill in reading and interpreting the Bible. This competent multidimensional reading of the Bible, especially as Barton (1989:443) and Jonker (1998:13; see also 1997:69-83) emphasize, can bring back the Bible from the professionals of the ivory tower to the pastors and ordinary Christians of the church. As far as this competent reading is concerned, Human (1994:8891) also provides a similar comprehensive integrated exegetical method for the Bible teacher who hardly knows anything about the specialized exegetical skills such as biblical languages.

From the viewpoint of competent reading, two considerations are basically needed to read the Bible multi-dimensionally.

Firstly, all the readers of the Bible should have a good overview of the communication process that is taking place. This competence enables the readers to ask relevant questions regarding their own interpretations.

Secondly, all the readers of the Bible should ask the question about reading skills (exegetical methods): "What methods does the text prompt to choose - or rather, require?" At the same time, the consistent interaction between text and context also gives rise to the question about reading skills: "What methods does the context prompt to choose - or rather, require?" Text and contexts, thus, determine which methods are relevant to the text's own multidimensional reading.

\section{BIBLIOGRAPHY}

Aristotle 1926. The Art of Rhetoric. Cambridge: Harvard.

Barton, J 1989. Should Old Testament Study be more Theological? Expository Times 100 (12):443-448.

Bright, J 1977. Covenant and Promise. London: SCM Press.

Brueggemann, W 1985. David's Truth. Philadelphia: Fortress Press.

Brueggemann, W 1995. The Psalms and the Life of Faith. Minneapolis: Fortress Press.

Childs, BS 1962. Memory and Tradition in Israel. London: SCM Press.

Cicero 1954. Rhetorica ad herennium. Cambridge: Harvard.

Clifford, RJ 1981. In Zion and David a New Beginning: An Interpretation of Psalm 78, in Halpern, B et al (eds.) Traditions in Transformation, 121-141. Winona Lake: Eisenbrauns.

Conradie EM et al 1995. Fishing for Jonah: Various Approaches to Biblical Interpretation. Bellville: University of the Western Cape Press.

De Moor, JC (ed.) 1995. Synchronic or Diachronic? Leiden: EJ Brill. 
Deist, FE et al 1982. From Eden to Rome. Pretoria: Van Schaik.

Gitay, Y 1993. Rhetorical Criticism, in McKenzie, SL and Haynes, SR (eds.) To Each its own Meaning, 135-149. Louisville: Westminster/John Knox Press.

Greenstein, EL 1990. Mixing Memory and Design: Reading Psalm 78. Prooftexts: A Journal of Jewish Literary History 10:197-218.

Human, DJ 1994. Reading the Texts of the Bible: With Illustrative Reference to Psalm 25. Scriptura 49:88-96.

Hyde, C 1988. The Remembrance of the Exodus in the Psalms. Worship 62(5):404-414.

Johnson, AR 1979. The Cultic Prophet and Israel's Psalmody. Cardiff: University of Wales Press.

Jonker, LC 1996. Plotting the Exegetical-hermeneutical Landscape. Scriptura 59:397-411.

Jonker, LC ca1996 Exclusivity and Variety. Kampen: Kok Pharos Publishing House.

Jonker, LC 1997. Bridging the Gap between Bible Readers and 'Professional' Exegetes. Old Testament Essays 10(1):69-83.

Jonker, LC 1998. Reading Jonah Multidimensionally. Scriptura 64:1-15.

Kennedy, GA 1984. New Testament Interpretation through Rhetorical Criticism. Chapel Hill: University of North Carolina Press.

Kidner, D 1975. Psalms 73-150. Leicester: Inter Varsity Press.

Kim, Y 1999. Reading Psalm 78 Multidimensionally. Potchefstroom: Potchefstroom University for Christian Higher Education (Unpublished dissertation).

Kim, Y and Van Rooy, HF 2000. Reading Psalm 78 Multidimensionally: The Textual Dimension. Scriptura 74:285-298.

Kim, Y and Van Rooy, HF 2002. Reading Psalm 78 Multidimensionally: The Authorial Dimension. To be published in Scriptura.

Kraus, HJ 1986. Theology of the Psalms. Minneapolis: Augsburg.

Kroll, WM 1987. Psalms: the Poetry of Palestine. Lanham: University Press of America.

Kutsch, E 1997. מִּרִית berîth obligation, in Jenni, E and Westermann, C (eds.) Theological Lexicon of the Old Testament, 256-266. Peabody: Hendrickson.

Labuschagne, JC 1966. The Incomparability of Yahweh in the Old Testament. Leiden: EJ Brill.

Lategan, BC 1992. Hermeneutics, in Freedman, DN (ed.) The Anchor Bible Dictionary. vol. 3, 149-154. New York: Doubleday.

Mays, JL 1994a. The Lord Reigns. Louisville: Westminster/John Knox Press.

Mays, JL 1994b. Psalms: Interpretation - a Bible Commentary for Teaching and Preaching. Louisville: John Knox Press.

McKnight, EV 1985. The Bible and the Reader. Philadelphia: Fortress.

Muilenburg, J 1969. Form Criticism and Beyond. Journal of Biblical Literature 88:1-18.

Noth, M 1963. The "Re-presentation" of the O.T. in Proclamation, in Westermann, C (ed.) Essays on Old Testament hermeneutics, 76-88. Atlanta: John Knox.

Patrick, D 1994. The Rhetoric of Revelation. Horizons in Biblical Theology 16:20-40.

Perdue, LG 1974. The Riddle of Psalm 49. Journal of Biblical Literature 93:533-542.

Richards, LO 1985. Expository Dictionary of Bible Words. Grand Rapids: Zondervan Publishing House. 
Sabourin, LSJ 1969. The Psalms: Their Origin and their Meaning. Vol. 2. New York: Alba House.

Tate, ME 1990. Psalm 51-100. Dallas: Word Books.

Tate, WR 1991. Biblical Interpretation: An Integrated Approach. Peabody: Hendrickson.

Trible, P 1994. Rhetorical Criticism: Context, Method, and the Book of Jonah. Minneapolis: Fortress Press.

Van Rooy, HF 1982. ברית in Jeremiah 11, in Deist, FE and Loader, JA (eds.) Papers read at the 24th meeting of Die Ou-Testamentiese Werkgemeenskap in Suider-Afrika, 93102. Stellenbosch: s.n.

Vriezen, TC 1958. An Outline of Old Testament Theology. Oxford: Basil Blackwell.

Walton, JH 1989. Ancient Israelite Literature in its Cultural Context. Grand Rapids: Zondervan Publishing House.

Watson, DF and Hauser, AJ 1994. Rhetorical Criticism of the Bible: A Comprehensive Bibliography with Notes on History and Methods. Leiden: EJ Brill.

Weinfeld, M 1975. בְּרִית berîth, in Botterweck, GJ et al (eds.) Theological Dictionary of the Old Testament, 253-279. Grand Rapids: Eerdmans.

Weiser, A 1962. The Psalms. Philadelphia: Westminster Press.

Westermann, C 1981. Praise and Lament in the Psalms. Atlanta: John Knox.

Wilson, GH 1997. The use of Royal Psalms at the 'Seams' of the Hebrew Psalter, in Clines, DJA (ed.). The Poetical Books, 73-83. Sheffield: Sheffield Academic Press.

Wuellner, W 1987. Where is Rhetorical Criticism Taking Us? Catholic Biblical Quarterly 49:448-463. 